\title{
Spectrophotometric Determination of Carbamazepine in Pharmaceutical Formulations Based on its Reaction with a Brominating Agent
}

\author{
Warda Rizgar*, Diyar S. Ali \\ Department of Chemistry, Science College, Salahaddin University, Erbil, Kurdistan Region, Iraq
}

\author{
${ }^{*}$ Corresponding author: \\ Warda Rizgar, \\ Department of Chemistry, \\ Science College, \\ Salahaddin University-Erbil, \\ Kurdistan Region, Iraq. \\ Tel: +9647501340433 . \\ E-mail: wardarzgar1994@ \\ yahoo.com
}

\section{Received: 30 May 2019 \\ Accepted: 29 August 2019 \\ Published: 01 December 2019}

\section{DOI}

10.25156/ptj.v9n2y2019.

pp42-49

\begin{abstract}
A B S TR A C T
Two accurate spectrophotometric methods described for the estimation of carbamazepine (CBZ) in both pharmaceutical and pure form. These methodologies are attached to the bromination of CBZ by bromine formed in instantly from the bromate-bromide reaction. The general procedure includes the additional of a known amount of bromate-bromide reagent in an acidic mediocre to CBZ. After the reaction is integrated, the unreacted bromine was reacted with a steady amount of methylene blue, and the absorbance was measured at $665 \mathrm{~nm}$ (method A) or, cresol red could be used for the reaction and the absorbance moderated at $517 \mathrm{~nm}$ (method B). Beer's law was submitted from 0.45 to $15.00 \mu \mathrm{g} / \mathrm{mL}$ CBZ with a molar absorptivity of $4.93 \times 10^{3} \mathrm{~L} / \mathrm{mol} . \mathrm{cm}$ for method $A$ and from 0.50 to $12.00 \mu \mathrm{g} / \mathrm{mL} \mathrm{CBZ}$ with a molar absorptivity of $1.37 \times 10^{4} \mathrm{~L} / \mathrm{mol}$.cm for method B. The proposed methods were effective for the determination of CBZ in tablets with great precision and accuracy.
\end{abstract}

Keywords: Bromate-bromide; Carbamazepine; Cresol red; Methylene blue; Spectrophotometry

\section{INTRODUCTION}

Carbamazepine (CBZ), also familiar as 5H-dibenz [b,f]-azepine-5-carboxamide (Index et al., 2006), is a tricyclic, mood stabilizing, an anticonvulsant drug which is often used in the therapy of bipolar disorder, and neuropathic soreness epilepsy. The drug is mentioned in the British Pharmacopoeia (2013) which expresses a highperformance liquid chromatography (HPLC) method for its dissection in tablet form (Abdulrahman et al., 2010).

The literature regarding the processes for the specification of CBZ in biological materials using different techniques is wide: LC (Džodić et al., 2009; Walker, 1988), flow injection (FI) spectrophotometry (Çomoğlu et al., 2006), FI chemiluminescence (CL) (Xiong et al., 2009), Gas chromatography (GC) (Liu et al., 1991; Kadioglu and Demirkaya, 2007), HPLC (Panchagnula et al., 1998; Yuan et al., 2003; Demirkaya and Kadioglu, 2005; Demirkaya and Kadioglu, 2008; Ulu, 2006), polarography (Zhang et al., 1993), FI-spectrofluorimetry (Huang et al., 2002), CL (Lee et al., 2003; Abed and Al-Abachi, 2015), and visible spectrophotometry (Rao and Murty, 1982; Agrawal et al., 1989).

Numerous instruments and materials have been used to detect pharmaceutical, including CL, FI, and chromatographic techniques (Walker, 1988; Liu et al., 1991; Panchagnula et al., 1998; Yuan et al., 2003; Demirkaya and Kadioglu, 2008; Džodić et al., 2009). However, many of these techniques involve complex procedures and require pretreatment. The procedural simplicity of visible spectrophotometry and its cost-effectiveness, selectivity, sensitivity, acceptable accuracy, good precision, and widespread availability in quality control laboratories make it a useful technique.

To the best of our knowledge, only one titrimetric method has been reported (Basavaiah and Abdulrahman, 2014), and many reports for the specification of CBZ in pharmaceuticals have involved the use of visible spectrophotometry. Rao and Murty, 1982, described a method established on the oxidation reaction between sodium metaperiodate and CBZ in the acidic moderate after heating for $1 \mathrm{~h}$. Before measuring the absorbance at $410 \mathrm{~nm}$, the chromogen must be extracted into n-butanol. Agrawal et al., 1989, demonstrated a method established on the reaction of hydroxyl ammonium chloride- $\mathrm{NaOH}$ with the amide group in CBZ under hot provisions, followup by reaction with ferric chloride in an $\mathrm{HCl}$-containing moderate and measurement of the absorbance at $510 \mathrm{~nm}$. Frag et al., 2012, reported the charge transfer and ion pair complexation reactions between CBZ and mosapride 
citrate. Another method described (Fadhel et al., 2017) sensitive spectrophotometric determination of CBZ, established on the oxidation of 2,4-dinitrophenylhydrazine by potassium periodate and coupling with CBZ in a base medium to form a stable yellowish-brown water-soluble dye with maximum absorption at $485 \mathrm{~nm}$. It is clear that researchers use visible spectrophotometry because of its accuracy, precision, and simplicity.

Herein, we report the optimization of two sensitive procedures for the determination of CBZ in dosage and pure forms. The developed methods utilize a bromatebromide mixture in acidic moderate as well as methylene blue (MB) and cresol red (CR) as auxiliary agents.

\section{Instruments}

All the spectral absorbance estimations were performed utilizing a Labomed, Inc., U.S.A. Advanced spectrophotometer furnished with a $1 \mathrm{~cm}$ coordinated cell.

\section{REAGENTS AND MATERIALS}

Pure CBZ standard powder was obtained from the State Company for Drug Industries and Medical Appliances, Samara-Iraq (SDI). All other chemical reagents were provided by "Awamedica" in Erbil-Iraq. Every single pharmaceutical tablet was conveyed from trading sources in the provincial market. All synthetic substances and reagents utilized were of analytical reagent grade and distilled water was utilized along the study.

\section{CBZ Stock Solution ( $1000 \mu \mathrm{g} / \mathrm{mL}$ )}

A stock standard arrangement of CBZ at a concentration of $1000 \mu \mathrm{g} / \mathrm{mL}$ was set up by melting $100 \mathrm{mg}$ of naive material in $20 \mathrm{~mL}$ of ethanol at that point diluting it to $100 \mathrm{~mL}$ with D.W in a $100 \mathrm{~mL}$ volumetric flask.

\section{Hydrochloric Acid Solution (1.0 mol/L)}

The $1.0 \mathrm{~mol} / \mathrm{L} \mathrm{HCl}$ arrangement was set up by diluting $41.45 \mathrm{~mL}$ of concentrated $\mathrm{HCl}$ in a $500 \mathrm{~mL}$ volumetric flask with distilled water. The arrangement was standardized utilizing a $\mathrm{Na}_{2} \mathrm{CO}_{3}$ solution.

\section{Potassium Bromate Solution (4.7 $\left.\times 10^{-3} \mathrm{~mol} / \mathrm{L}\right)$}

A stock standard arrangement of potassium bromate $\mathrm{KBrO}_{3} ; 4.7 \times 10^{-3} \mathrm{~mol} / \mathrm{L}$ was set up by dissolve $0.196 \mathrm{~g}$ of $\mathrm{KBrO}_{3}$ in a $250 \mathrm{~mL}$ volumetric flask with water. Other solutions were prepared daily from the standard solution by serial dilution in a $100 \mathrm{~mL}$ calibrated flask.

\section{Potassium Bromide Solution (4.7 $\left.\times 10^{-2} \mathrm{~mol} / \mathrm{L}\right)$}

A stock standard arrangement of potassium bromide $\mathrm{KBr}$; $4.7 \times 10^{-2} \mathrm{~mol} / \mathrm{L}$ was set up by dissolve $1.398 \mathrm{~g}$ of $\mathrm{KBr}$ in a $250 \mathrm{~mL}$ volumetric flask with water. Other solutions were prepared daily from the standard solution by serial dilution in a $100 \mathrm{~mL}$ volumetric flask.

\section{MB Solution $\left(3.1 \times 10^{-4} \mathrm{~mol} / \mathrm{L}\right)$}

In advance, $1 \times 10^{-2} \mathrm{~g}$ of $\mathrm{MB}$ powder was dissolved in $50 \mathrm{~mL}$ of water, at that point diluted in a $100 \mathrm{~mL}$ volumetric flask with water to set up $\left(3.1 \times 10^{-4} \mathrm{~mol} / \mathrm{L}\right)$ the final $\mathrm{MB}$ solution.

\section{CR Solution $\left(2.4 \times 10^{-3} \mathrm{~mol} / \mathrm{L}\right)$}

In advance, $1 \times 10^{-2} \mathrm{~g}$ of CR powder was dissolved in $20 \mathrm{~mL}$ of water, at that point diluted in a $100 \mathrm{~mL}$ calibrated flask with water to set up $\left(2.4 \times 10^{-4} \mathrm{~mol} / \mathrm{L}\right)$ the final CR solution.

\section{Assay Procedure for Tablets}

A sum of 10 tablets, including CBZ, were ground into a fine powder and precisely weighed $(486 \mathrm{mg})$ then dissolved in a $200 \mathrm{~mL}$ calibrated flask. Subsequently, $100 \mathrm{~mL}$ of ethanol was included and the flask was mechanically shaken for 15 min. The blend was then weakened to mark with water, blended and strained thoroughly Whatman filter paper no 42 . Then, $5 \mathrm{~mL}$ of the solution was diluted to $50 \mathrm{~mL}$ with ethanol:water (1:1) diluent.

\section{Spectrophotometry using MB (Method A)}

Into a progression of $25 \mathrm{~mL}$ volumetric flasks, $1.0 \mathrm{~mL}$ of $1 \mathrm{~mol} / \mathrm{L} \mathrm{HCl}$ was added follow-up by $2.0 \mathrm{ml}$ of bromatebromide $\left(1.0 \mathrm{~mL}\right.$ of potassium bromate $\left[4.7 \times 10^{-4} \mathrm{~mol} / \mathrm{L}\right]$ and $1.0 \mathrm{~mL}$ of potassium bromide $\left.4.7 \times 10^{-3} \mathrm{~mol} / \mathrm{L}\right]$ ). The flask was let to stand for 1 min (Time 1) with snatchy shaking. Subsequently, $3 \mathrm{ml}$ of $100 \mu \mathrm{g} / \mathrm{mL}$ CBZ $(12 \mu \mathrm{g} / \mathrm{mL})$ was suffixed to a flask and allowed to equilibrate for $2 \mathrm{~min}$ (Time 2). After that, $(4 \mathrm{~mL}$ of $3.1 \times$ $\left.10^{-3} \mathrm{~mol} / \mathrm{L}\right) \mathrm{MB}$ solution was added to the mixture and diluted to the flask volume with water and stirring well (Time 3). Afterward, the absorbance of the arrangement was measured at $665 \mathrm{~nm}$.

\section{Spectrophotometry using CR (Method B)}

Into a series of $25 \mathrm{~mL}$ calibrated flasks, $1.0 \mathrm{~mL}$ of $1 \mathrm{~mol} / \mathrm{L} \mathrm{HCl}$ was added follow-up by $2.0 \mathrm{~mL}$ of bromate-bromide $(1.0 \mathrm{~mL}$ of potassium bromate $\left[4.7 \times 10^{-4} \mathrm{~mol} / \mathrm{L}\right]$ and $1.0 \mathrm{~mL}$ of potassium bromide $\left.\left[4.7 \times 10^{-3} \mathrm{~mol} / \mathrm{L}\right]\right)$. The flask was let to stand for $1 \mathrm{~min}$ (Time 1) with snatchy shaking. Then, $3 \mathrm{~mL}$ of $100 \mu \mathrm{g} / \mathrm{mL}$ CBZ $(8.0 \mu \mathrm{g} / \mathrm{mL})$ was suffixed to the flask and equilibrated for $2 \mathrm{~min}$ (Time 2). After that, $(4 \mathrm{~mL}$ of $2.4 \times 10^{-3} \mathrm{~mol} / \mathrm{L}$ ) CR solution was suffixed to the mixture and diluted to the flask volume with water and stirring well (Time 3). Afterward, the absorbance of the solution was measured at $517 \mathrm{~nm}$. 


\section{RESULTS AND DISCUSSION}

The measure of CBZ in the samples was resolved utilizing the acidified the bromate-bromide blend. We developed two spectrophotometric procedures for the CBZ investigation utilizing bromine as a green brominating agent. Bromine produced by the acid assault on the (bromate-bromide) blend was utilized established on the basis of green chemistry (Anastas and Warner, 1998), which empowers the reserve of the highly toxic and dangerous liquid bromine. The developed methods were eco-friendly, did not form hazardous byproducts, are inexpensive, and easily available. These methods are indirect and established on the extra of excess (bromate-bromide) in and acidic moderate containing the drug. After the reaction is integrate, the unreacted bromine was estimated by reaction with a steady amount of $\mathrm{MB}$ or $\mathrm{CR}$. The reaction was monitored by estimating the change in the absorbance of MB or CR at 665 or $517 \mathrm{~nm}$, respectively.

\section{Chemistry}

The reaction between CBZ and bromine in an acidic medium involves electrophilic substitution and addition reactions.

$\mathrm{BrO}_{3}^{-}+5 \mathrm{Br}^{-}+6 \mathrm{H}^{+} \longrightarrow 3 \mathrm{Br}_{2}+3 \mathrm{H}_{2} \mathrm{O}$

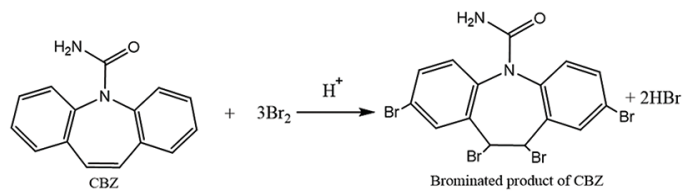

\section{Suggested Mechanism}

For method A

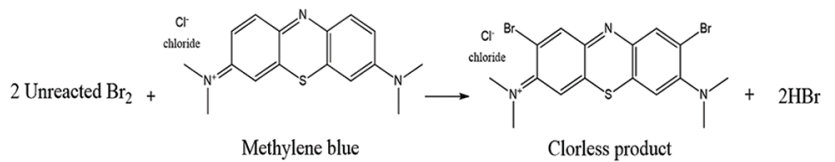

For method B

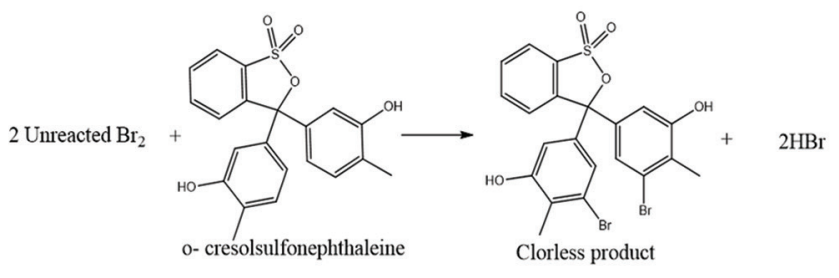

The nitrogen atom appended to the benzene ring as an activating group, allowing for the direct bromination to the para and ortho positions in both rings. Be that as it may, the bromination occurred just at the para positions - due to the steric effects of the amide, minimizing the yield of the orthoproduct. The expansion of bromine occurs at the double bond somewhere C3 and C4 in the azepine ring (Mosher, 1992).

\section{Optimization of Reaction Variables}

The parameters related to the production of the colored product were individually varied while fixing all others to optimize the reaction conditions.

\section{Effect of Potassium Bromate Concentration}

The effect of potassium bromate concentration on the absorbance $(\mathrm{MB})$ of the shaded item was examined between $1.8 \times 10^{-5}-1.5 \times 10^{-4} \mathrm{~mol} / \mathrm{L}$ [Figure 1a]. It was found that the maximum absorbance of the blue-green product was obtained with $7.5 \times 10^{-5} \mathrm{~mol} / \mathrm{L}$ potassium bromate. Concentrations higher than this value resulted in decreased absorbance. Therefore, $7.5 \times 10^{-5} \mathrm{~mol} / \mathrm{L}$ potassium bromate was for subsequent studies. The impact of potassium bromate concentration on the absorbance (CR) of the orange product was studied from $1.8 \times 10^{-5}-1.3 \times 10^{-4} \mathrm{~mol} / \mathrm{L}$ potassium bromate. The maximum absorbance of the colored product was obtained at a potassium bromate concentration of $9.4 \times$ $10^{-5} \mathrm{~mol} / \mathrm{L}$, above which absorbance decreased [Figure $1 \mathrm{~b}$ ]. Therefore, $9.4 \times 10^{-5} \mathrm{~mol} / \mathrm{L}$ potassium bromate was utilization for the ensuing work.

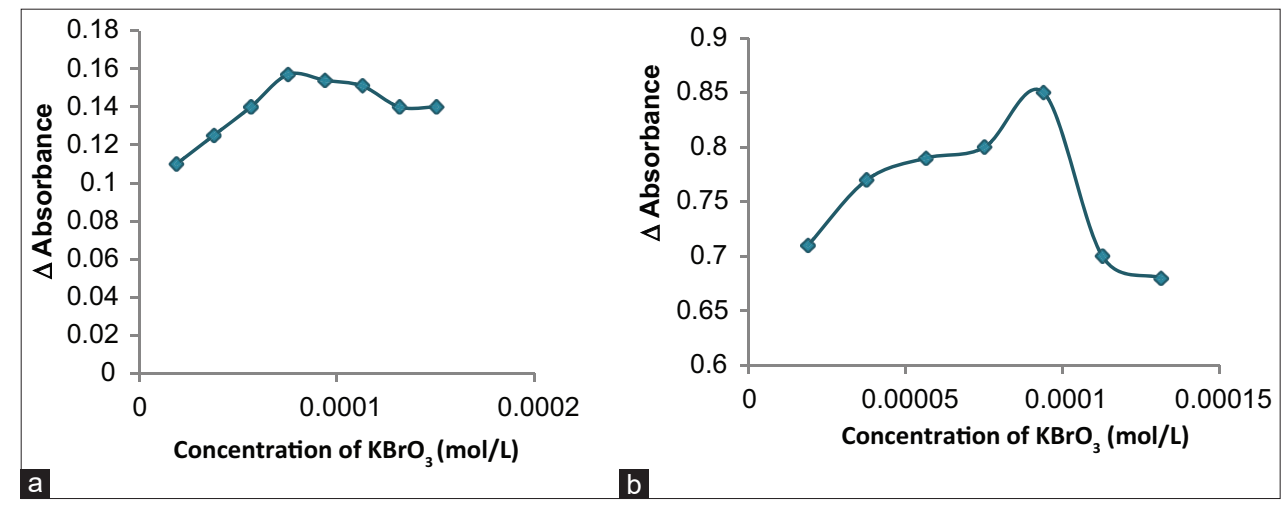

Figure 1: (a) Effect of potassium bromate concentration (b) effect of potassium bromate concentration 


\section{Effect of Potassium Bromide Concentration}

The study of potassium bromide concentration (MB) showed that the reaction depended on $\mathrm{KBr}$ as an oxidizing agent. The absorbance was optimized at $3.7 \times 10^{-4} \mathrm{~mol} / \mathrm{L}$ $\mathrm{KBr}$, as shown in Figure 2a. Above this concentration, decreased absorbance was observed. The impact of the potassium bromide concentration on the absorbance of the colored product (CR) was investigated between $3.5 \times 10^{-5}$ and $3.0 \times 10^{-4} \mathrm{~mol} / \mathrm{L} \mathrm{KBr}$. The optimum value of the absorbance was observed when the concentration

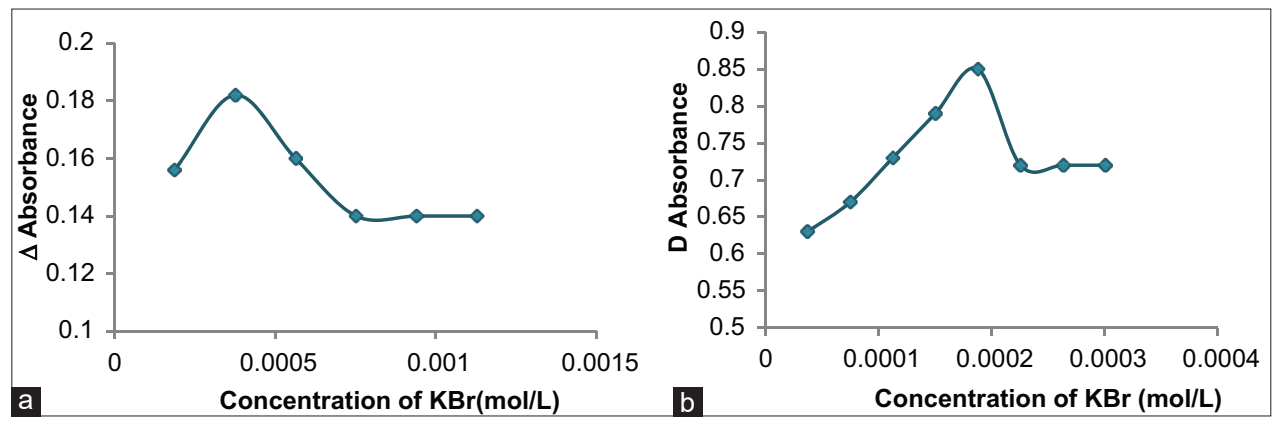

Figure 2: (a) Effect of potassium bromide concentration (b) effect of potassium bromide concentration

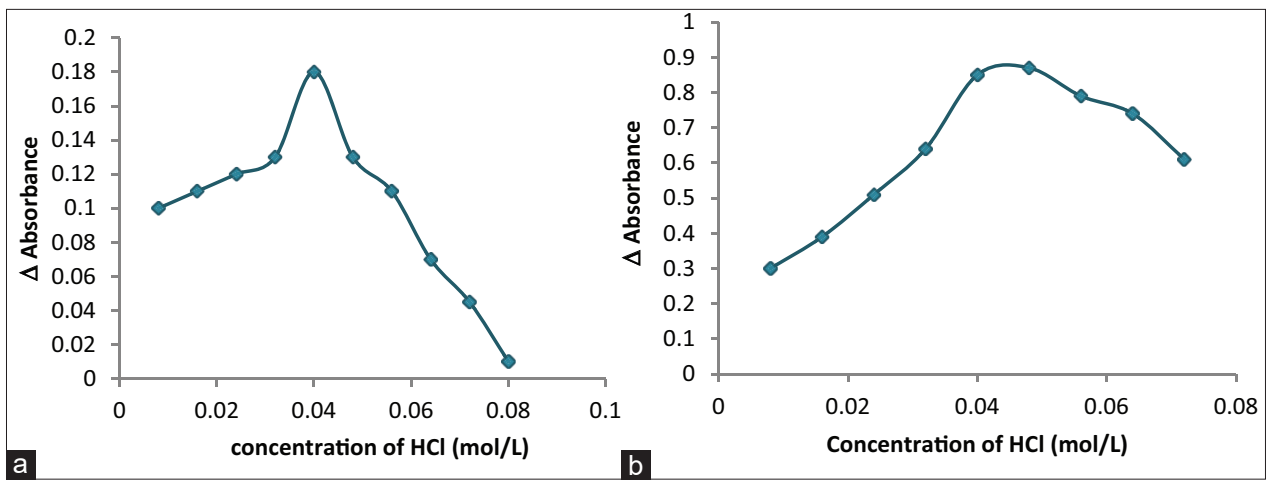

Figure 3: (a) Effect of $\mathrm{HCl}$ concentration (b) effect of $\mathrm{HCl}$ concentration

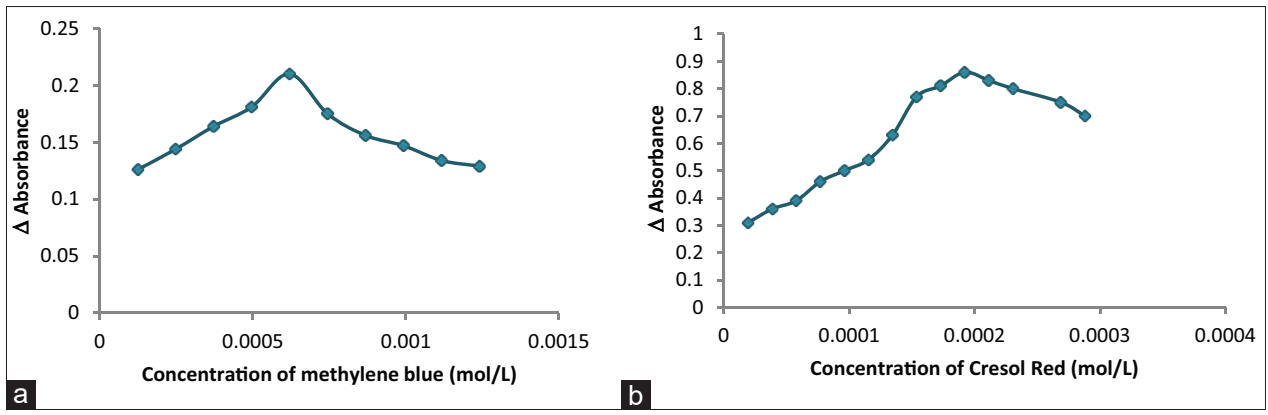

Figure 4: (a) Effect of methylene blue concentration (Method A) (b) effect of cresol red concentration (Method B)

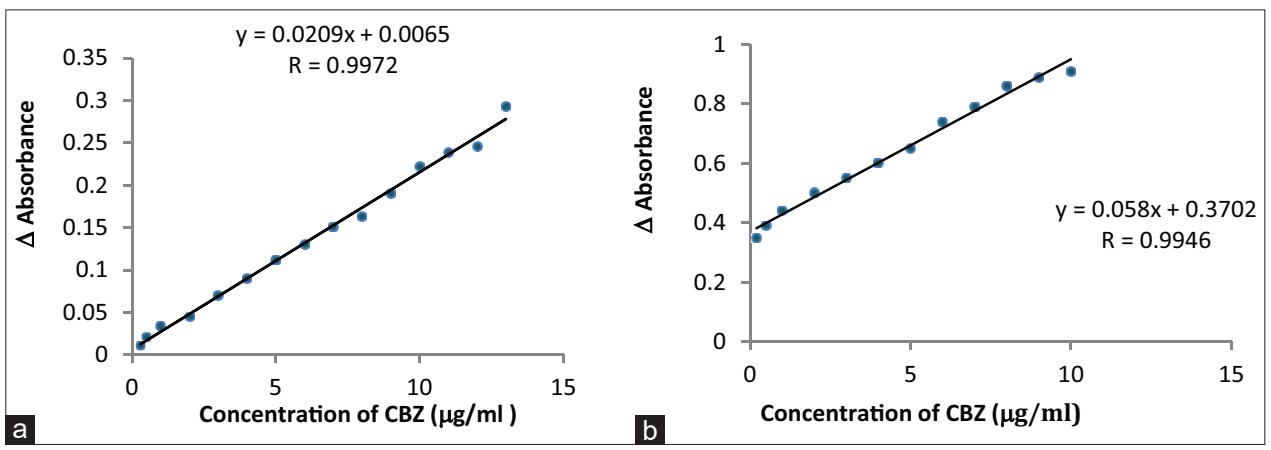

Figure 5: (a) Calibration graph for Method A (b) calibration graph for Method B 
Table 1: Effect of mixing time for both methods

\begin{tabular}{|c|c|c|c|c|}
\hline Methods & Time & $\begin{array}{c}\Delta \mathbf{A} \\
(\text { Time 1) }\end{array}$ & $\begin{array}{c}\Delta \mathbf{A} \\
\text { (Time 2) }\end{array}$ & $\begin{array}{c}\Delta \mathbf{A} \\
\text { (Time 3) }\end{array}$ \\
\hline \multirow{14}{*}{$\begin{array}{l}\text { Spectrophotometric } \\
(\text { method A) }\end{array}$} & 0.5 & 0.195 & 0.179 & 0.25 \\
\hline & 1 & 0.21 & 0.185 & 0.25 \\
\hline & 1.5 & 0.203 & 0.194 & 0.25 \\
\hline & 2 & 0.198 & 0.21 & 0.25 \\
\hline & 2.5 & 0.189 & 0.218 & 0.25 \\
\hline & 3 & 0.181 & 0.22 & 0.25 \\
\hline & 3.5 & & 0.229 & 0.25 \\
\hline & 4 & & 0.234 & 0.25 \\
\hline & 4.5 & & 0.24 & 0.25 \\
\hline & 5 & & 0.251 & 0.25 \\
\hline & 5.5 & & 0.245 & 0.25 \\
\hline & 6 & & 0.228 & 0.25 \\
\hline & 6.5 & & 0.22 & 0.25 \\
\hline & 7 & & 0.219 & 0.25 \\
\hline \multirow{8}{*}{$\begin{array}{l}\text { Spectrophotometrc } \\
\text { (method B) }\end{array}$} & 0.5 & 0.78 & 0.7 & 0.86 \\
\hline & 1 & 0.86 & 0.76 & 0.86 \\
\hline & 1.5 & 0.7 & 0.81 & 0.86 \\
\hline & 2 & 0.65 & 0.863 & 0.86 \\
\hline & 2.5 & 0.65 & 0.79 & 0.86 \\
\hline & 3 & 0.65 & 0.71 & 0.86 \\
\hline & 3.5 & & 0.67 & 0.86 \\
\hline & 4 & & 0.6 & 0.86 \\
\hline
\end{tabular}

Table 2: Analytical and regression parameters

\begin{tabular}{lcc}
\hline Parameter & Method A & Method B \\
\hline I maximum $(\mathrm{nm})$ & 665 & 517 \\
Molar absorptivity $(\mathrm{L} / \mathrm{mol} / \mathrm{cm})$ & 4938 & 13703 \\
Limit of detection $(\mu \mathrm{g} / \mathrm{mL})$ & 0.315 & 0.086 \\
Limit of quantification & 0.956 & 0.263 \\
Correlation coefficient $(r)$ & 0.9972 & 0.9946 \\
\hline
\end{tabular}

of $\mathrm{KBr}$ was $1.8 \times 10^{-4} \mathrm{~mol} / \mathrm{L}$ [Figure 2b]. Therefore, $\left(1.8 \times 10^{-4} \mathrm{~mol} / \mathrm{L}\right) \mathrm{KBr}$ used during the subsequent work.

\section{Effect of Hydrochloric Acid Concentration}

The influence of $\mathrm{HCl}$ on the absorbance of the bluegreen product $(\mathrm{MB})$ was investigated at concentrations ranging between $8.0 \times 10^{-3}$ and $8.0 \times 10^{-2} \mathrm{~mol} / \mathrm{L}$. Figure 3 a shows that the optimum concentration of $\mathrm{HCl}$ was $4.0 \times 10^{-2} \mathrm{~mol} / \mathrm{L}$, above which decreased signal was observed. Therefore, $4.0 \times 10^{-2} \mathrm{~mol} / \mathrm{L} \mathrm{HCl}$ was used for the subsequent studies. The impact of hydrochloric acid on the absorbance of the orange product (CR) was investigated in the concentration range between $8.0 \times 10^{-3}$ and $-7.2 \times 10^{-2} \mathrm{~mol} / \mathrm{L}$. The absorbance optimized at an $\mathrm{HCl}$ concentration of $4.8 \times 10^{-2} \mathrm{~mol} / \mathrm{L}$, above which the absorbance decreased, as shown in Figure 3b. Therefore, $4.8 \times 10^{-2} \mathrm{~mol} / \mathrm{L} \mathrm{HCl}$ was used for the subsequent studies.

\section{Effect of MB}

The effectiveness of the MB concentration on the absorbance was investigated. The absorbance increased until the MB concentration reached $6.2 \times 10^{-5} \mathrm{~mol} / \mathrm{L}$, above which the absorbance decreased, as shown in Figure $4 \mathrm{a}$. Therefore, $7.4 \times 10^{-4} \mathrm{~mol} / \mathrm{L} \mathrm{MB}$ was used for further study.

\section{Effect of CR}

The effect of CR concentration on the absorbance of the product was investigated. The absorbance increased when until a concentration of $1.9 \times 10^{-4} \mathrm{~mol} / \mathrm{L}$, above which the absorbance decreased, as shown in Figure 4b. Therefore, $1.9 \times 10^{-4} \mathrm{~mol} / \mathrm{L}$ was used for subsequent work.

Table 3: Intraday and interday precision and accuracy studies

\begin{tabular}{|c|c|c|c|c|c|c|c|}
\hline \multirow[t]{2}{*}{ Method } & \multirow[t]{2}{*}{ CBZ taken } & \multicolumn{3}{|c|}{ Intraday $(n=8)$} & \multicolumn{3}{|c|}{ Interday $(n=8)$} \\
\hline & & CBZ founda & Precision ${ }^{b}$ & Accuracy ${ }^{c}$ & CBZ found ${ }^{a}$ & Precision $^{b}$ & Accuracy $^{c}$ \\
\hline \multirow{3}{*}{$\begin{array}{l}\text { Spectrophotometric } \\
\text { (method A) }\end{array}$} & 1.0 & 1.025 & 1.52 & 2.5 & 1.03 & 1.86 & 3.0 \\
\hline & 6.0 & 5.82 & 3.46 & -3.0 & 6.05 & 2.20 & 0.83 \\
\hline & 11 & 10.88 & 1.53 & -1.09 & 10.73 & 1.43 & -2.45 \\
\hline \multirow{3}{*}{$\begin{array}{l}\text { Spectrophotometric } \\
\text { (method B) }\end{array}$} & 1.0 & 1.041 & 3.72 & 4.1 & 0.989 & 4.6 & -1.1 \\
\hline & 4.0 & 3.97 & 5.03 & -0.75 & 4.0 & 5.10 & 0.0 \\
\hline & 9.0 & 8.90 & 2.68 & -1.12 & 8.91 & 1.63 & -1.1 \\
\hline
\end{tabular}

${ }^{\mathrm{a}}$ Mean value of $\mathrm{n}$ determination, ${ }^{\mathrm{b}}$ Relative standard deviation $\%,{ }^{\mathrm{c}}$ Error $(\%)=\left[(\right.$ found - taken)/taken $]{ }^{*} 100$. CBZ: Carbamazepine

Table 4: Determination of CBZ in commercial pharmaceutical formulations with the proposed and the standard methods

\begin{tabular}{|c|c|c|c|c|c|c|c|}
\hline \multirow[t]{2}{*}{ Formulation } & \multirow{2}{*}{$\begin{array}{l}\text { Product manufacture and } \\
\text { country }\end{array}$} & \multirow{2}{*}{$\begin{array}{l}\text { Labeled amount } \\
\text { (mg/tablet) }\end{array}$} & \multicolumn{3}{|c|}{ CBZ found (mg) per tablet } & \multirow[t]{2}{*}{ E \%MB } & \multirow[t]{2}{*}{ E \%CR } \\
\hline & & & $\begin{array}{l}\text { Proposed } \\
\text { method MB }\end{array}$ & $\begin{array}{l}\text { Proposed } \\
\text { method CR }\end{array}$ & $\begin{array}{l}\text { Standard } \\
\text { method }\end{array}$ & & \\
\hline \multirow{5}{*}{ Tables } & Carbamazepin (Aristo) & 200 & 7.73 & 7.79 & 7.64 & 1.16 & 1.92 \\
\hline & Tegrertol (Novartis) & 200 & 7.97 & 7.89 & 8.08 & -1.38 & -2.4 \\
\hline & Carbasam (S.D.I - Iraq) & 200 & 7.81 & 7.86 & 7.74 & 0.89 & 1.52 \\
\hline & Carbazepin Awa (Awamedica) & 200 & 7.89 & 7.91 & 7.82 & 0.88 & 1.13 \\
\hline & CBZ (Iranian) & 200 & 7.93 & 7.96 & 7.92 & 0.0012 & 0.5 \\
\hline & \multicolumn{3}{|c|}{ Method A } & \multicolumn{4}{|c|}{ Method B } \\
\hline $\mathrm{t}$ table $=2.77$ & \multicolumn{2}{|c|}{$\mathrm{t}$ calculated $=1.19$} & & \multicolumn{4}{|c|}{ t calculated $=1.156$} \\
\hline $\mathrm{F}$ table $=6.39$ & \multicolumn{2}{|c|}{ F calculated $=0.324$} & & \multicolumn{4}{|c|}{ F calculated $=0.138$} \\
\hline
\end{tabular}




\section{Physical Optimization}

To optimize all conditions for the determination of CBZ by spectrophotometric methods, physical parameters were studied at room temperature, as shown in Table 1.

The reaction can occur at room temperature by an increase or decrease temperature no influence in the reaction rate and absorbance spectra.

\section{Method Validation}

\section{Linearity}

The calibration graph of the spectrophotometric method used for the quantitative specification of $\mathrm{CBZ}$ was obtained, under the optimized reaction conditions [Table 2]. The graph was established by plotting the CBZ concentration

Table 5: Robustness results of method A

\begin{tabular}{|c|c|c|c|c|c|}
\hline \multirow[t]{2}{*}{ Parameters } & \multicolumn{2}{|c|}{ CBZ ( $\mu \mathrm{g} / \mathrm{mL})$} & \multirow{2}{*}{$\begin{array}{c}\text { Found } \\
(\mathrm{X} \pm \mathrm{SE} \text {; SD) }\end{array}$} & \multirow{2}{*}{$\begin{array}{l}\text { Recovery } \\
(\%)\end{array}$} & \multirow{2}{*}{$\begin{array}{l}\text { RSD } \\
(\%)\end{array}$} \\
\hline & Sample & Added & & & \\
\hline \multicolumn{6}{|l|}{ Wavelength } \\
\hline \multirow[t]{2}{*}{660} & 5 & 3 & $\begin{array}{c}(7.996 \pm 0.053 \\
0.092)\end{array}$ & 99.95 & 1.15 \\
\hline & 5 & 5 & $\begin{array}{c}(9.96 \pm 0.068 \\
0.119)\end{array}$ & 99.6 & 1.19 \\
\hline \multirow[t]{2}{*}{670} & 5 & 3 & $\begin{array}{c}(8.096 \pm 0.066 \\
0.115)\end{array}$ & 101.2 & 1.42 \\
\hline & 5 & 5 & $\begin{array}{c}(10.03 \pm 0.090 \\
0.156)\end{array}$ & 100.3 & 1.55 \\
\hline \multicolumn{6}{|l|}{ Time } \\
\hline \multicolumn{6}{|l|}{ Time 1} \\
\hline 0.5 & 5 & 5 & $\begin{array}{c}(9.951 \pm 0.015 \\
0.027)\end{array}$ & 99.51 & 0.27 \\
\hline 1.5 & 5 & 5 & $\begin{array}{c}(10.05 \pm 0.049 \\
0.085)\end{array}$ & 100.5 & 0.84 \\
\hline \multicolumn{6}{|l|}{ Time 2} \\
\hline 4.5 & 5 & 5 & $\begin{array}{c}(9.96 \pm 0.0046 \\
0.008)\end{array}$ & 99.6 & 0.08 \\
\hline 5.5 & 5 & 5 & $\begin{array}{c}(10.0 \pm 0.0310 \\
0.054)\end{array}$ & 100 & 0.54 \\
\hline
\end{tabular}

CBZ: Carbamazepine, SE: Standard error, SD: Standard deviation, RSD: Relative standard deviation in $\mu \mathrm{g} / \mathrm{mL}$ against the distinction in absorbance $(\Delta \mathrm{A})$. The calibration graph was linear in the concentration range between 0.45 and $15.00 \mu \mathrm{g} / \mathrm{mL}$ [Figure 5a] for method $\mathrm{A}$ and $0.50-12.00 \mu \mathrm{g} / \mathrm{mL}$ [Figure $5 \mathrm{~b}$ ] for method B. The analytical and regression parameters are listed in Table 2.

\section{Accuracy and precision}

Method precision and accuracy were determined using three equal quantities of the pure CBZ material, and every estimation was performed multiple times (8 times). The relative standard deviation (\%) and relative error $(\%)$ were estimated for different CBZ groups. The results showed great accuracy and precision. Excellent inter- and intra-day reproducibility was observed, and a progression of analyses was connected for the equivalent diverse convergences of the medication, the estimations were improved the situation bury and intradays with 8 and 5 redundancies separately. Table 3 shows all day-to-day relative standard deviation and relative error values.

\section{Analysis of pharmaceutical preparations}

The preferred methods were effectively applied for CBZ assurance in the pharmaceutical formulation (tablet). The outcomes acquired were contrasted to those obtained using the standard techniques (British Pharmacopoeia, 2013) of the Student's t-test for accuracy and f-test for precision [Table 4].

\section{Robustness}

Ideally, the detection limit and productivity of the proposed indirect spectrophotometric technique would be unaffected by small variations under measurement conditions encountered during typical utilization. Several method parameters, such as wavelength and time, were varied within a reasonable range, and the quantitative impact of these changes was determined for the pre-analyzed sample solution containing $(5.0 \mu \mathrm{g} / \mathrm{mL}) \mathrm{CBZ}$. The results of the robustness tests are shown in Tables 5 and 6 , indicating that the proposed technique is robust.

Table 6: Robustness results of method B

\begin{tabular}{|c|c|c|c|c|c|}
\hline \multirow[t]{2}{*}{ Parameters } & \multicolumn{2}{|c|}{ CBZ $(\mu \mathrm{g} / \mathrm{mL})$} & \multirow[t]{2}{*}{ 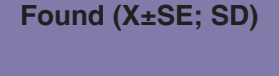 } & \multirow[t]{2}{*}{ Recovery (\%) } & \multirow[t]{2}{*}{ RSD (\%) } \\
\hline & Sample & Added & & & \\
\hline \multicolumn{6}{|l|}{ Wavelength } \\
\hline \multirow[t]{2}{*}{510} & 5 & 2 & $(6.973 \pm 0.043 ; 0.075)$ & 99.61 & 1.07 \\
\hline & 5 & 4 & $(8.903 \pm 0.061 ; 0.105)$ & 98.92 & 1.17 \\
\hline \multirow[t]{2}{*}{525} & 5 & 2 & $(6.933 \pm 0.072 ; 0.125)$ & 99.04 & 1.80 \\
\hline & 5 & 4 & $(8.920 \pm 0.051 ; 0.088)$ & 99.11 & 0.98 \\
\hline \multicolumn{6}{|l|}{ Time } \\
\hline \multicolumn{6}{|l|}{ Time 1} \\
\hline 0.5 & 5 & 2 & $(7.063 \pm 0.076 ; 0.133)$ & 100.9 & 1.88 \\
\hline 1.5 & 5 & 2 & $(7.036 \pm 0.082 ; 0.142)$ & 100.5 & 2.01 \\
\hline \multicolumn{6}{|l|}{ Time 2} \\
\hline 4.5 & 5 & 2 & $(6.980 \pm 0.061 ; 0.105)$ & 99.7 & 1.50 \\
\hline 5.5 & 5 & 2 & $(7.043 \pm 0.040 ; 0.070)$ & 100.6 & 0.99 \\
\hline
\end{tabular}

CBZ: Carbamazepine, SE: Standard error, SD: Standard deviation, RSD: Relative standard deviation 
Table 7: Effect of interference of $(4 \mu \mathrm{g} / \mathrm{mL})$ of the drug for the first method (MB)

\begin{tabular}{lcccc}
\hline $\begin{array}{l}\text { Interfering } \\
\text { species }\end{array}$ & Conc. $\mu \mathrm{g} / \mathrm{ml}$ & $\begin{array}{c}\Delta \\
\text { Absorbance } \\
\text { without } \\
\text { interference }\end{array}$ & $\begin{array}{c}\Delta \\
\text { Absorbance } \\
\text { with }\end{array}$ & interference \\
\hline $\begin{array}{l}\text { Sucrose } \\
\text { Titanium } \\
\text { dioxide }\end{array}$ & 4 & 0.09 & 0.092 & 2.22 \\
Lactose & 4 & 0.09 & 0.087 & -3.33 \\
Sodium & 4 & 0.09 & 0.091 & 1.11 \\
sterate & & 0.09 & 0.094 & 4.44 \\
Glucose & 4 & 0.09 & 0.089 & -1.11 \\
Starch & 4 & 0.09 & 0.093 & 3.33 \\
Mixture of all & Above & 0.09 & 0.093 & 3.33 \\
& concentration & & & \\
\hline
\end{tabular}

${ }^{a}$ Average of five replication measurement. MB: Methylene blue

Table 8: Effect of interference of $(4 \mu \mathrm{g} / \mathrm{mL})$ of the drug for the second method CR

\begin{tabular}{lcccc}
$\begin{array}{l}\text { Interfering } \\
\text { species }\end{array}$ & Conc. $\mu \mathrm{g} / \mathrm{ml}$ & $\begin{array}{c}\Delta \\
\text { Absorbance } \\
\text { without } \\
\text { interference }\end{array}$ & $\begin{array}{c}\Delta \\
\text { Absorbance } \\
\text { with }\end{array}$ & $\begin{array}{c}\text { E\% } \% \\
\text { interference }\end{array}$ \\
\hline $\begin{array}{l}\text { Sucrose } \\
\begin{array}{l}\text { Titanium } \\
\text { dioxide }\end{array}\end{array}$ & 4 & 0.602 & 0.61 & 1.328 \\
$\begin{array}{l}\text { Lactose } \\
\text { Sodium }\end{array}$ & 4 & 0.602 & 0.607 & 0.83 \\
sterate & 4 & 0.602 & 0.598 & -0.66 \\
$\begin{array}{l}\text { Glucose } \\
\text { Starch }\end{array}$ & 4 & 0.602 & 0.621 & 3.15 \\
$\begin{array}{l}\text { Mixture } \\
\text { of all }\end{array}$ & 4 & 0.602 & 0.618 & 2.657 \\
\hline
\end{tabular}

CR: Cresol red

\section{Selectivity}

To evaluate the effect of interference, the effects of impurities were examined for CBZ determination. The selection of interferences compounds was performed according to the composition of the drug samples. The influence of the presence of common additives such as magnesium stearate-, lactose, titanium dioxide-, starch-, sucrose, and glucose- was tested, and the results are shown in Tables 7 and 8 for methods A and B.

\section{CONCLUSION}

Estimation of CBZ by indirect procedure has been attempted. In the optimization of different parameters for the proposed methods, the concentration of all components was taken into account; optimum conditions were considered to be those affording maximum intensity, greatest possible signal stability, and maximum linearity. The reaction can be carried out at room temperature and the sample preparation is minimal, no pretreatment is required, and the analysis is simple, accurate, and precise. The cost of chemical standard and reagents are minimal (since no large amount of expensive reagents was consumed). The detection limit data indicated that the microgram quantity of CBZ can be accurately determined.

\section{REFERENCES}

Abdulrahman, S. A. M., K. Basavaiah and H. Doddarevanna. 2010. Use of eco-friendly brominating agent for the spectrophotometric determination of $\mathrm{CBZ}$ in pharmaceutical formulations. Malay. 8: 11-24.

Abed, S. S. and M. Q. Al-Abachi. 2015. Spectrophotometric determination of phenylephrine hydrochloride and salbutamol sulphate drugs in pharmaceutical preparations using diazotized metoclopramide hydrochloride. Baghdad Sci. J. 12: 167-177.

Agrawal, Y., R. Giridhar and S. Menon. 1989. Spectrophotometric determination of carbamazepine. Indian J. Pharm. Sci. 51: 75-77.

Anastas, P. T. and J. C. Warner. 1998. Principles of green chemistry. In: Green Chemistry: Theory and Practice. Oxford University Press, New York. p29-56.

Basavaiah, K. and S. A. Abdulrahman. 2014. Utilization of bromination reactions for the determination of carbamazepine using bromate bromide mixture as a green brominating agent. Arabian J. Chem. 7: 297-305.

Çomoğlu, T., N. Gönül, E. Şener, A. Dal and M. Tunçel. 2006. Determination of carbamazapine by flow-injection analysis: Its application to tablet analysis and dissolution studies. J. Liq. Chromatogr. Relat. Technol. 29: 2677-2690.

Demirkaya, F. and Y. Kadioglu. 2005. Determination of carbamazepine using RP-HPLC method in pharmaceutical preparations. FABAD J. Pharm. Sci. 30: 78.

Demirkaya, F. and Y. Kadioglu. 2008. Determination of Carbamazepine in Pharmaceutical Preparations and Pure Forms Using HPLC-DAD, First Order-and Second Order-derivative Spectrophotometric Methods. Proceedings of the International Workshop on New Trends in Science and Technology, Ankara, Turkey.

Džodić, P., L. Živanović, A. Protić, M. Zečević and B. Jocić. 2009. Chemometrically assisted development and validation of LC for simultaneous determination of carbamazepine and its impurities iminostilbene and iminodibenzyl in solid dosage form. Chromatographia. 70: 1343.

Fadhel, S. R., N. I.Abdulla and I. D. Sulaiman. 2017. Spectrophotometric determination of carbamazepine via oxidative coupling reaction with 2, 4-dinitrophenyl hydrazine. Ibn AL-Haitham J. Pure Appl. Sci. 29: 226-238.

Frag, E. Y., M. Zayed, M. Omar, S. E. Elashery and G. G. Mohamed. 2012. Spectrophotometric determination of carbamazepine and mosapride citrate in pure and pharmaceutical preparations. Arab. J. Chem. 5: 375-382.

Huang, C., Q. He and H. Chen. 2002. Flow injection photochemical spectrofluorimetry for the determination of carbamazepine in pharmaceutical preparations. J. Pharm. Biomed. Anal. 30: 59-65.

Index, M., M. O'Neil, P. Heckelman and C. Koch. 2006. The Merck Index. Merck and Co., Whitehouse Station NJ.

Kadioglu, Y. and F. Demirkaya. 2007. Determination of carbamazepine in pharmaceutical dosage form using GC-FID. Chromatographia. 66: 169-172.

Lee, S. H., M. Li and J. K. Suh. 2003. Determination of carbamazepine by chemiluminescence detection using chemically prepared tris (2, 2'-bipyridine) ruthenium (III) as oxidant. Anal. Sci. 19: 903-906. 
Liu, F., Y. Wu and B. Zou. 1991. Determination of carbamazepine in tablets by gas chromatography. Sepu. 9: 64-65.

Mosher, M. 1992. Organic chemistry. (Morrison, Robert Thornton; Boyd, Robert Neilson). J. Chem. Educ. 69: A305.

Panchagnula, R., K. Kaur, I. Singh and C. Kaul. 1998. Determination of carbamazepine in plasma, urine and formulations by highperformance liquid chromatography. Pharm. Pharmacol. Commun. 4: 401-406.

Rao, G. and S. Murty. 1982. Colorimetric determination of carbamazepine in pharmaceutical dosage forms. East. Pharm. 25: 111-112.

Ulu, S. T. 2006. Determination of carbamazepine in pharmaceutical preparations using high-performance liquid chromatography and derivative spectrophotometry. Turk. J. Pharm. Sci. 3: 123-139.
Walker, E. 1988. Liquid chromatographic determination of carbamazepine in tablets. J. Assoc. Official Anal. Chem. 71: $523-525$.

Xiong, X. Y., Q. Z. Zhang, F. M. Xiong and Y. H. Tang. 2009. Determination of carbamazepine in pharmaceuticals by flow injection chemiluminescence method. Fenxi Shiyanshi. 28: 56-59.

Yuan, X., H. Jun and J. Mccall. 2003. Determination of carbamazepine in uncoated and film-coated tablets by HPLC with UV detection. Anal. Lett. 36: 1197-1210.

Zhang, Z., S. Chen, W. Huang and F. Xu. 1993. Polarographic determination of carbamazepine in the presence of sodium lauryl sulfate. Yao Xue Xue Bao. 28: 312-316. 